\title{
The role of Christian institutions in witnessing to students of the Muslim faith: The case of the University of Eastern African Baraton in Kenya
}

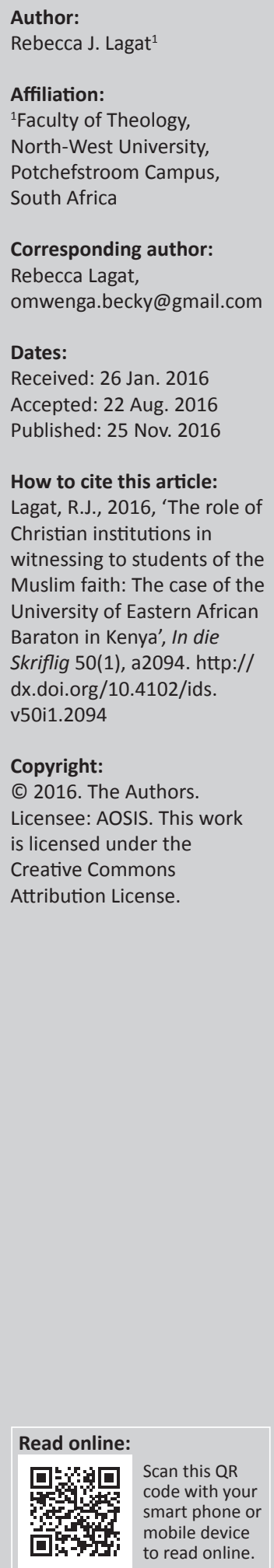

\begin{abstract}
The University of Eastern African, Baraton (UEAB) mission is concerned with providing a religious education in a holistic environment. This includes education in the gospel globally by recruiting students from all spheres including those of other faiths. The aim is witnessing to them during their four-year stay at the institution with the hope of introducing them to the Adventist faith. The main focus of this study was to establish whether the UEAB was true to its basic philosophy of witnessing to people of other faiths - in this case by engaging Muslim students. A qualitative-research design was adopted for the study. The data was collected by means of document analysis, interviews and observations. Fifteen administrators and twelve Muslim students were used for the investigation. The study investigated the strategies and channels to evangelise students from other faiths contextually, and ascertain whether the $\mathrm{UEAB}$ indeed is living up to its own vision and mission. Recommendations are put forward to engage students from other faiths through more personnel and, for instance, new strategies to engage the Muslims on campus through friendship evangelisation.
\end{abstract}

\section{Introduction}

The UEAB is an institution of higher learning owned and operated by the Seventh-day Adventist (SDA) Church (Bradfield 2014:132). The SDA Church is a worldwide, multiracial, multicultural and conservative Christian denomination with an established educational system that encompasses 106 senior colleges and universities worldwide (Patrick 2010; Grajales, Leon \& Ellas 2010). The UEAB, Eldoret in Kenya is one such institution.

The UEAB Adventist Church operates the University as part of its missionary objectives (Ramirez, Ashley \& Cort 2014:58; Francis \& Astley 1995). The redemption offered by Christ and preached by the church, and the maturity of the experience that results from this proclamation are the two important aspects of this mission (Wiklander 1998:99). The UEAB has the commission to fulfil its mission and to evangelise to its students who include those of other faiths and are not limited to Muslims (the population selected for the present study). In this sense the UEAB has to operationalise its mission statement and follow its objectives. The mission and the objectives of the UEAB are to provide and advance a holistic Christian quality education to the youth with the aim of equipping them with the necessary skills to serve God and humanity. The objectives also include a balanced educational programme that gives each student the opportunity to develop spiritually, mentally, physically and socially. This curriculum encourages the students to understand, appreciate and adopt a Christian lifestyle and value system by providing appropriate religious instruction in the classroom; offering a variety of religious services and activities; and fostering an atmosphere on campus where Christian principles find practical expression in all relationships (UEAB 2008).

This implies that the UEAB must be able to conceptualise and develop spiritual programmes and activities that introduce students to nature and enhance their spiritual life (Gardener 2010:198). This article investigates the influence of the UEAB on the Muslim student's spiritual life and how the institution has lived up to its promise by delivering to this community - as guided by the mentioned mission statement (Whitehouse 1998:41).

\section{Background}

Protestant Christian mission to Muslims began in earnest in the 19th century with the rise of the Evangelical movement (Laing 2013:28; Ernst 2011). During the missionary outreach of the 'great century', theologians generally begrudged the hope of salvation to anyone outside the Christian 
faith (Aleaz 2010:197). Missionary treatises, dealing with Islam, were written mainly for the purpose of facilitating conversion. It thus establishes the superiority of Christianity over Islam and criticising the religion of the Oriental churches (Ivermee 2014:255). Few adherents of the more tolerant approach would characterise much of the more recent missionary reflection on Islam (Smith 1998:357; cf. Siddiqui 2010:242-243; Brown 1976:24-38).

The 21st century has seen a change from early predictions of the imminent demise of Islam to a generally greater appreciation for it and even for the role of the prophet Muhammad (Osindo 2005; White 2011:40). Unfortunately, the main theme of evangelical literature is still built around hopes of the ultimate conversion of all Muslims to Christianity (Barna 1998:72). However, recent missionary literature on Islam has indicated a clear tension between the approaches of dialogue and that of witnessing (Smith 1998:358; Schielke 2007).

In establishing such institutions, the Seventh-day Adventist Church competes with other larger church groups that are globally better positioned. These groups utilise vast resources coupled with an attitude of earnestness and enthusiasm to spread their religious influence worldwide by targeting the children and youth. This state of affairs makes winning the hearts and minds of young people the crucial strategy for the church (Taizé 2014). In this area, the future for the smaller denominations will either be won or lost. It is indeed true that the future of the church in the world is in the hands of young believers (Barger 1966:16-17).

\section{Seventh-day Adventist education}

According to Greenleaf (2005:25), certain Adventist programmes brought about a social uplifting within the Adventist education and its educators. The Adventist education did not only provide social benefits that fostered personal well-being. It also linked these blessings to the redemptive mission of Christianity. Nevertheless, Adventist schools do not enjoy universal recognition. Moreover, it appears that some indigenous people distrust Adventist education because of its sectarian character and the perception that it forms part of a larger imperial movement. While a strong argument can be advanced in this regard, teachers and educators within this system would argue that it is unrealistic to assume that every student should adopt this type of education, since it provides a choice to accept Christianity (Gould 2014:167).

The UEAB's motto, vision and mission draw on philosophy from the church's commitment to mission, as stated below by Wiklander (2002):

The Seventh-day Adventist church is committed to the mission of making disciples of all people from every nation, tribe, tongue, and people group. This is a commitment to communicate God's truth in the efficient and intelligible way to people in various cultures and conceptual systems. (p. 1)
The typical basic need of a mission organisation is to make more disciples for Christ (Volz 2014:472). With this aim in mind the UEAB, as a mission school, took on the challenge of ministering to its students in order to lead them toward a personal relationship with Jesus Christ and prepare them for eternity (Aleaz 2011:103). Muslim students form part of the UEAB community. Thus, the University is faced with the challenge of applying the spiritual aspect of the abovementioned mission statement to the Muslim students despite their differing religious background. Even though the UEAB has put certain spiritual programmes in place for its students, the question remains whether the programmes do cater for the Muslim students at their point of need.

\section{College evangelism}

Various schools of thought have pointed out the vital role of education as the major factor responsible for the strength and vigour of societies (Hewitt 2014; cf. Volz 2014). It is generally accepted that humans consist of two aspects, namely spirit (inner) and body (outer), and therefore require an educational principle that harmonises their bodily needs with the spiritual inspiration (Scott \& Randallb 2014). The reason is that the religious motive is innate in humans' nature and is evident in people's orientation before they fall victim to various kinds of spiritual blindness. Hence, if this primary principle of religion could be made the basis of education, individuals would be able to develop further and strive for perfection in its light, and thus avoiding deviation from this motive (Sayyid \& Majtaba 1997:92-93; cf. Gould 2014).

Directness through language, Parshall (2002:658-659) implies that one can address a problem without offending the person. Western cultures tend to separate the person from the problem, the action or the idea. Thus, Westerners often claim the freedom to criticise ideas, behaviours and failures of others. This criticism is typically prefaced by statements such as 'I have nothing against you personally', and 'I say this to you as a friend'. However, people, and even Westerners, do react negatively when hearing such phrases, because they often do not distinguish between the person and the idea or behaviour (Duanne 1993:49).

Christians have shown major confusion about the nature of the cultural forms (e.g. rituals and ceremonies) that are used regularly (Dizon 2012:8). Many assume that forms such as baptism, the Lord's Supper, preaching and other church customs are sacred as such (Mugambi 2013). However, from an anthropological perspective it becomes clear that the form or ritual is important, not because it is sacred as such, but because meanings attached to that form are considered sacred. It is seen as idolatry to exalt the form to a position where the focus is on the form rather than on what God seeks to communicate through that form (Kraft 1996:10).

Sophie (2000:19) states that a university ought to produce a measure of intellectual humility in its practitioners regarding the perceived importance of their own discipline. However, a university that functions effectively will also, through the 
encounters of the diverse disciplines, model ways in which cultural traditions, religious loyalties and ethnic identities can co-exist. This co-existence should not imply indifference between the groups, but rather a climate of mutual and honest questioning in which the differing commitments are not automatically contrasted, but can be mutually enriching.

Brummet (1990:21) points out that identifying with people of another culture makes it possible to communicate the message that is brought to them and the gospel that is intended to be shared. In a sense, the content of the gospel comprises the biblical message as a whole that portrays or declares God's good news in many different ways to people of diverse cultures. At times people may resist the gospel message, not because they are antagonistic to Christ or Christianity, but because they perceive it as a threat to their culture and the solidarity experienced within their society (Sauer 2013:56).

One effective way to engage Muslim students at UEAB is friendship evangelisation. Friendship evangelisation bases its emphasis on the care and love upon people of other faiths (Doughlas 1994). This is because it emphasises a dedicated life of service, a practice of social justice unto all and a realisation of human welfare (Siemens 1997). Used and practiced by the Lord Jesus, friendship evangelisation was adopted by apostles and has been used in many parts of the world today (Doughlas 1994). This remains one of the effective ways to win souls to God today. By emulating Christ and his apostles, thousand Adventist Christian students and personnel would well apply this method to reach out to the handful Muslim students at UEAB.

\section{Culture and evangelism}

One of the major challenges in cross-cultural evangelism is finding a strategy to present the gospel without transferring certain cultural baggage (McVay 2005:50; Aden \& Benner 1989). In effect, Christians face the on-going dilemma: they are called to share their faith, but this faith is inevitably framed in their own personal cultural worldview (Shaw 2014:261). As a result, believers tend to urge people to accept the good news of God in Christ according to their own understanding of the content. However, it is a known fact that throughout church history there has been a variety of theological designs, beginning from the Scriptures as a source itself. The question is whether Luke's audience could have understood the theology of the book of Hebrews. Would it be possible for the Apostles Paul and James to understand each other's motives? Could the Gentile churches and the Jerusalem congregation have understood each other from the outset? (Fee 1994:35)

Pratt (2005:97) states that, according to the Holy Scriptures, people have become comfortable to accept various viewpoints - some of which often are quite contradictory. The Christian view presents a multitude of paradoxes, for example, on the true day of worship based on the teachings of the Sabbath rest or the quest of the rapture.
However, people tend to be less able to cope with theological diversity and tension in contemporary church thought. They accept others as fellow believers only if those believers can share their confession and commitment (Makondo \& Makondo 2011; cf. Hiebert 2002:378). These theological battles existed within the church even from biblical times, but there is a concern about hardened viewpoints creeping into the efforts based on an evangelistic predisposition (Shibley 1997:29; cf. Taylor 1972:119). It is thus important to distinguish the essential aspect of the gospel message from the nonessential, cultural baggage in engaging Muslims where Western and Eastern worldviews inevitably meet.

Where worldviews meet, the focus typically falls on culture as a phenomenon. A culture cannot survive if it does not satisfy certain basic needs of its members. The extent to which a certain culture achieves the fulfilment of these needs will determine its ultimate success (Shaw 2014). Therefore, 'success' is measured by the values of the culture as such, rather than by those of a cultural 'outsider' (Kraft 2002:385). A culture should provide the production and distribution of goods and services that are considered necessary for its members' existence. It must provide biological continuity by the reproduction to its members. In addition, a culture must inculcate new members to become fully functioning adults. It must maintain order among its members as well as outsiders. Finally, culture must motivate its members to survive and engage in the activities that are necessary for their daily survival (Haviland 1989:295; cf. Sauer 2013).

Cultural anthropology provides the conceptual tools with which to extract the biblical principles from individual cultural forms in order to make these universally applicable to culture (Hesselgrave 2000:29). For example, Paul, according to 1 Corinthians 16:20, encourages believers to greet their brethren with a holy kiss. This is a cultural form of the biblical principle that fellow believers should be greeted warmly. This biblical principle can also be applied in cross-cultural contact. In North-America and Africa the cultural form is a hearty handshake, while in South America it would be an embrazo [good hug] (Grunland \& Mayers 1979:28).

The mission of the Seventh-day Adventist Church is witnessing Christ across cultures. Beach (1998:30; cf. Augsburger 1986) suggests that organisations such as universities or schools, which are operated by the church, must be pragmatic and flexible since they face abnormal situations. Where sociocultural and/or academic circumstances make it impossible to operate by means of regular church structures, the mentioned churches have to function as best they can, utilising informal structures in the most effective way (Eastman 1997:22; cf. Berry et al. 2002).

\section{Research questions}

The study was guided by the following research questions:

- What are the institutions doing to fulfil the mandate of witnessing to students from other faiths with special reference to Muslims? 
- How many Muslim students have joined the Adventist movement from the launching of the UEAB to date?

- Which programmes inform the arm responsible for engaging Muslim students?

\section{Objectives of the study}

The objectives of this study can be stated as follows:

- It determines which spiritual programmes the UEAB offers to the students of other faiths.

- It establishes the relevance of the spiritual programmes offered by the UEAB to the enrolled Muslim students.

- It ascertains the mutual problems faced by the UEAB and Muslim students.

\section{Methodology}

The research entails a case study that utilises both qualitative and quantitative designs. It is based on a documentary analysis of baptismal records and churches' evangelical programmes. The particular focus is on the relevance of each activity as related to witnessing the gospel.

I, as the researcher, undertook the role of evaluator and drew on my knowledge of cross-cultural mission to people of other faiths. Interviews were undertaken to justify the documentary analysis in order to provide clarification and insight into the matters at hand, namely witnessing and evangelisation. Observation formed part of the study. I visited the UEAB's chapel and worshipped with the students for a minimum of three services to ascertain how the worship activities took place.

\section{Findings}

The presentation and analysis of the data are divided into two parts: data analysis for the general population who participated in the study, and for the different sub-groups who formed the population of the study. In this way the section analyses the respondents' perception of whether the UEAB is spiritually ministering to the Muslim students as part of the church's mentioned mission statement. The data was analysed in relation to the research questions presented above.

\section{Data processing}

A total of $12(80.0 \%)$ questionnaires out of the 15 from the administrators, and 12 questionnaires (100.0\%) from the Muslim students, dually filed, were returned by respondents. The data was fed into the computer and into the package of a social science programme (SPSS). The results of the tests are reported in Table 1.

Table 1 indicates that most of the respondents (50.0\%) are first-year students at the UEAB, two of them (25.0\%) secondyear students, two (16.7\%) are busy with their third year, while the rest $(16.7 \%)$ are in their fourth year. It is also evident from the same table that, during their early

\begin{tabular}{|c|c|c|c|}
\hline Item & Response & Frequency & $\%$ \\
\hline \multirow{5}{*}{$\begin{array}{l}\text { For how long have you been in } \\
\text { the University of Eastern Africa } \\
\text { Baraton? }\end{array}$} & 1 Year & 6 & 50.0 \\
\hline & 2 Years & 2 & 16.7 \\
\hline & 3 Years & 2 & 16.7 \\
\hline & 4 and Above & 2 & 16.7 \\
\hline & Total & 12 & 100.0 \\
\hline $\begin{array}{l}\text { Growing up in a Muslim home } \\
\text { environment during early } \\
\text { childhood }\end{array}$ & Yes & 12 & 100.0 \\
\hline \multirow{3}{*}{$\begin{array}{l}\text { Getting elementary education } \\
\text { from a Muslim school }\end{array}$} & No & 4 & 33.3 \\
\hline & Yes & 8 & 66.7 \\
\hline & Total & 12 & 100.0 \\
\hline \multirow[t]{3}{*}{ Enrolment for Islamic Madrasa } & No & 2 & 16.7 \\
\hline & Yes & 10 & 83.3 \\
\hline & Total & 12 & 100.0 \\
\hline \multirow[t]{3}{*}{ Respondents' marital status } & Single & 10 & 83.3 \\
\hline & Married & 2 & 16.7 \\
\hline & Total & 12 & 100.0 \\
\hline \multirow{3}{*}{$\begin{array}{l}\text { Person responsible for paying } \\
\text { Muslim student's school fee }\end{array}$} & Parents & 8 & 66.7 \\
\hline & Others & 4 & 33.3 \\
\hline & Total & 12 & 100.0 \\
\hline $\begin{array}{l}\text { Receiving the teaching of Jesus } \\
\text { Christ before joining the UEAB }\end{array}$ & Yes & 12 & 100.0 \\
\hline
\end{tabular}

childhood, all the students (100.0\%) grew up in a Muslim environment with their parents.

It is further clear that more than half of the respondents $(66.7 \%)$ received their elementary education in a Muslim school, while the rest (33.3\%) did not. The table also shows that the majority of the Muslim students (83.3\%) are enrolled for the Muslim Madrasa at the Mosque under the guidance of the Kadhi to learn more about the Islamic religion as opposed to the two $(16.7 \%)$ who did not.

On the issue of marital status, the table further indicates that the majority $(83.3 \%)$ of the respondents are single with only three students who are married $(66.7 \%)$. The fees are paid by the respondents' parents, while the rest is taken care of by individuals from sources not indicated in the study. Finally, the findings show that all (100.0\%) of the Muslim respondents did have knowledge of the teaching of Jesus Christ before joining UEAB.

According to Table 2, most of the administrators (58.3\%) covered in this study have worked for the UEAB for a tenure ranging between 1 to 5 years, two $(16.7 \%)$ have worked for the institution between 11 to 15 years, two others $(16.7 \%)$ worked for 16 years and above, while only one $(8.3 \%)$ has worked for 6 to 10 years. The table further indicates that most of the respondents $(83.3 \%)$ have had an encounter with someone from the Muslim community, while only two $(16.7 \%)$ had not.

On the issue of interest to interact with Muslim students, the majority $(83.3 \%)$ of the administrators showed interest to understand the Muslim community, while only two (16.7\%) were not interested.

Regarding prior training to engage people of other faiths and especially Muslims, the majority $(83.3 \%)$ of the respondents 
admitted that they have no training on Muslim evangelism, with only two (16.7\%) who underwent a form of training.

Table 2 also indicates that most of the respondents (83.3\%) did have close contact with the Muslim students at the

TABLE 2: Administrators' personal background information.

\begin{tabular}{lccc}
\hline Item & Response & Frequency & \% \\
\hline Number of years of service in & 1 -5 Years & 7 & 58.3 \\
the University of Eastern Africa & 6-10 Years & 1 & 8.3 \\
Baraton & 11-15 Years & 2 & 16.7 \\
& 16 Years and above & 2 & 16.7 \\
& Total & 12 & 100.0 \\
Prior encounter with Muslim & No & 2 & 16.7 \\
students & Yes & 10 & 83.3 \\
& Total & 12 & 100.0 \\
Interest in understanding the & No & 2 & 16.7 \\
Muslim community & Yes & 10 & 83.3 \\
& Total & 12 & 100.0 \\
Prior training on ministry to the & No & 10 & 83.3 \\
Muslim community & Yes & 2 & 16.7 \\
& Total & 12 & 100.0 \\
Prior interaction with the & No & 2 & 16.7 \\
Muslim students at the UEAB & Yes & 10 & 83.3 \\
& Total & 12 & 100.0 \\
\hline
\end{tabular}

University, while only two $(16.7 \%)$ responded that they have never had any such relationship.

From Table 3, it is clear that the majority of the student respondents $(83.3 \%)$ were of the opinion that most of the spiritual programmes offered at UEAB are not flexible enough to accommodate the Muslim students' spiritual growth. On this matter, only two (16.7\%) agreed that the programmes are flexible. On the same item, seven (58.3\%) administrators agreed that the programmes are flexible, three (25.0\%) contended that the programmes are not flexible, while the remaining two $(16.7 \%)$ were not certain whether the programmes do take care of the Muslim students. This difference in concept is in line with what one administrator said when responding to a question on programs that assist the Muslim students to grow in Christian faith.

All of the Muslim students (10.0\%) responded negatively on the question whether the UEAB's spiritual activities do take care of Muslim students' spiritual needs by building their teachings from what they already understand from their Muslim teaching. Five (41.7\%) administrators agreed on the same issue, the same number $(41.7 \%)$ disagreed,

TABLE 3: Spiritual programmes offered at the UEAB in relation to Muslim students.

\begin{tabular}{|c|c|c|c|c|c|}
\hline \multirow[t]{2}{*}{ Items } & \multirow[t]{2}{*}{ Response } & \multicolumn{2}{|c|}{ Students } & \multicolumn{2}{|c|}{ Administrator } \\
\hline & & $F$ & $\%$ & $F$ & $\%$ \\
\hline \multirow{4}{*}{$\begin{array}{l}\text { Do you think the Adventist spiritual } \\
\text { programmes offered at you UEAB are } \\
\text { flexible to accommodate Muslim students } \\
\text { in their spiritual growth? }\end{array}$} & Disagree & 10 & 83.3 & 3 & 25.0 \\
\hline & Uncertain & - & - & 2 & 16.7 \\
\hline & Agree & 2 & 16.7 & 7 & 58.3 \\
\hline & Total & 12 & 100.0 & 12 & 100.0 \\
\hline \multirow{4}{*}{$\begin{array}{l}\text { Do the UEAB's spiritual activities take care } \\
\text { of the Muslim students' spiritual needs by } \\
\text { building their teachings from what they } \\
\text { already understand from the Muslim } \\
\text { teaching? }\end{array}$} & Disagree & 12 & 100.0 & 5 & 41.7 \\
\hline & Uncertain & - & - & 2 & 16.7 \\
\hline & Agree & - & - & 5 & 41.7 \\
\hline & Total & 12 & 100.0 & 12 & 100.0 \\
\hline \multirow{4}{*}{$\begin{array}{l}\text { Does the everyday worshipping activity at } \\
\text { the UEAB give a Muslim student an } \\
\text { opportunity to understand the principle of } \\
\text { Christian teaching? }\end{array}$} & Disagree & - & - & 2 & 16.7 \\
\hline & Uncertain & 8 & 66.7 & 1 & 8.3 \\
\hline & Agree & 4 & 33.3 & 9 & 75.0 \\
\hline & Total & 12 & 100.0 & 12 & 100.0 \\
\hline \multirow{4}{*}{$\begin{array}{l}\text { Are the Adventist teachings systematic } \\
\text { enough to give a Muslim student a clear } \\
\text { picture of the relationship of God and Isa? }\end{array}$} & Disagree & 6 & 50.0 & 2 & 16.7 \\
\hline & Uncertain & & - & - & - \\
\hline & Agree & 6 & 50.0 & 12 & 83.3 \\
\hline & Total & 12 & 100.0 & 12 & 100.0 \\
\hline \multirow{5}{*}{$\begin{array}{l}\text { Do you think the University has introduced } \\
\text { her Muslim students to the so called } \\
\text { Christian environment? }\end{array}$} & Disagree & 4 & 33.3 & 7 & 58.3 \\
\hline & Uncertain & 1 & 8.3 & 2 & 16.7 \\
\hline & Agree & 4 & 33.3 & 3 & 25.0 \\
\hline & Missing & 3 & 25.0 & - & - \\
\hline & Total & 12 & 100.0 & 12 & 100.0 \\
\hline \multirow{4}{*}{$\begin{array}{l}\text { Do you think some general requirements } \\
\text { incorporating Christian perspective are } \\
\text { handled in a way that they can give a } \\
\text { Muslim student a better understanding of } \\
\text { Christianity than before? }\end{array}$} & Disagree & 8 & 66.7 & 1 & 8.3 \\
\hline & Uncertain & 2 & 16.7 & 3 & 25.0 \\
\hline & Agree & 2 & 16.7 & 8 & 66.7 \\
\hline & Total & 12 & 100.0 & 12 & 100.0 \\
\hline \multirow{5}{*}{$\begin{array}{l}\text { Does the University chaplain's office take } \\
\text { care of a Muslim student's spiritual needs } \\
\text { within the campus as a Muslim student? }\end{array}$} & Disagree & 8 & 66.7 & 1 & 8.3 \\
\hline & Uncertain & 3 & 25.0 & 8 & 66.7 \\
\hline & Agree & - & - & 3 & 25.0 \\
\hline & Missing & 1 & 8.3 & - & - \\
\hline & Total & 12 & 100.0 & 12 & 100.0 \\
\hline \multirow{4}{*}{$\begin{array}{l}\text { During worship time, do you think the } \\
\text { service takes care of the Muslim students } \\
\text { as part of the congregation with a different } \\
\text { spiritual background? }\end{array}$} & Disagree & 8 & 66.7 & 4 & 33.3 \\
\hline & Uncertain & 2 & 16.7 & 1 & 8.3 \\
\hline & Agree & 2 & 16.7 & 7 & 58.3 \\
\hline & Total & 12 & 100.0 & 12 & 100.0 \\
\hline
\end{tabular}


whilst two were uncertain about whether the activities actually do take care of the Muslim students.

It is also evident from Table 3 that most Muslim students $(66.7 \%)$ were uncertain whether the everyday worship activity at the UEAB did give them the opportunity to understand the principle of Christian teaching, while four (33.3\%) agreed that the worship activity contributes. Most of the administrators $(75.0 \%)$ agreed that the everyday activities in reality give the Muslim students the opportunity to understand Christianity, two (16.7\%) disagreed, while only one $(8.3 \%)$ was uncertain on this matter.

Half (50.0\%) of the Muslim students agreed that the Adventist teachings are systematic enough to give them a clear picture of the relationship of God and Jesus Christ, and the remaining half $(50.0 \%)$ disagreed. Most of the administrators (83.3\%) agreed on this issue, with only two (16.7\%) disagreeing.

Reading from Table 3, it is evident that four (33.4\%) of the students are of the opinion that the University has introduced its Muslim students to the so-called Christian environment, whereas the same number disagreed with this opinion. In addition, three $(25.0 \%)$ did not respond to this question, while one $(8.7 \%)$ was uncertain. Most of the administrators (58.3\%) disagreed that the UEAB has introduced its Muslim students to Christianity, while three (25.0\%) agreed, and two $(16.7 \%)$ were uncertain about this issue.

Most of the student respondents (66.7\%) disagreed that some general requirements for incorporating a Christian perspective are handled in such a way that they can give a Muslim student a better understanding of Christianity than before they joined the institution (Bowman \& Small 2010). Two $(16.7 \%)$ agreed, while the remaining two were uncertain. In the same vein, most of the administrators $(66.7 \%)$ agreed with this opinion, three $(25.0 \%)$ were uncertain, while one disagreed.

Table 3 further indicates that most Muslim students (66.7\%) disagreed that the UEAB chaplain's office does take care of a Muslim student's spiritual needs within the campus as a Muslim student, three (25\%) were uncertain, while one $(8.3 \%)$ did not respond to this question. More than half of

TABLE 4: Adventist students' and administrators' way of life in relation to Muslim students' way of life.

\begin{tabular}{|c|c|c|c|c|c|}
\hline \multirow[t]{2}{*}{ Items } & \multirow[t]{2}{*}{ Response } & \multicolumn{2}{|c|}{ Students } & \multicolumn{2}{|c|}{ Administrator } \\
\hline & & $F$ & $\%$ & $F$ & $\%$ \\
\hline \multirow{4}{*}{$\begin{array}{l}\text { Do you think the way the Adventists handle } \\
\text { their activities can make someone decide to } \\
\text { change their faith from Islam to Christianity? }\end{array}$} & Disagree & 10 & 83.3 & 2 & 16.7 \\
\hline & Uncertain & 2 & 16.7 & 2 & 16.7 \\
\hline & Agree & & & 8 & 66.7 \\
\hline & Total & 12 & 100.0 & 12 & 100.0 \\
\hline \multirow{4}{*}{$\begin{array}{l}\text { Do you think the Adventist's way of life gives a } \\
\text { clear picture of how God really expect his } \\
\text { children to live? }\end{array}$} & Disagree & 6 & 50.0 & 2 & 16.7 \\
\hline & Uncertain & 2 & 16.7 & 1 & 8.3 \\
\hline & Agree & 4 & 33.3 & 9 & 75.0 \\
\hline & Total & 12 & 100.0 & 12 & 100.0 \\
\hline \multirow{4}{*}{$\begin{array}{l}\text { Do you think the Adventist students and } \\
\text { administrators really look at Muslims as } \\
\text { descendants of Abraham despite their } \\
\text { different religious affiliations? }\end{array}$} & & 6 & 50.0 & 3 & 25.0 \\
\hline & Uncertain & & & 2 & 16.7 \\
\hline & Agree & 6 & 50.0 & 7 & 58.3 \\
\hline & Total & 12 & 100.0 & 12 & 100.0 \\
\hline \multirow{4}{*}{$\begin{array}{l}\text { Does the University engage the Muslim } \\
\text { students in her spiritual activities, irrespective } \\
\text { of their religious affiliation given that they } \\
\text { form part of her religious students' } \\
\text { community? }\end{array}$} & Disagree & 6 & 50.0 & 4 & 33.3 \\
\hline & Agree & 4 & 33.3 & 3 & 25.0 \\
\hline & Missing & 1 & 8.3 & 1 & 8.3 \\
\hline & Total & 12 & 100.0 & 12 & 100.0 \\
\hline \multirow{4}{*}{$\begin{array}{l}\text { Does the University recognize the special } \\
\text { occasions in a Muslim's student's life (e.g. The } \\
\text { Holy Month of Ramadhan, Worship time, Zalat, } \\
\text { Sawm) and gives them time to take part? }\end{array}$} & Disagree & 10 & 83.3 & 5 & 41.7 \\
\hline & Uncertain & - & - & 2 & 16.7 \\
\hline & Agree & 2 & 16.7 & 5 & 41.7 \\
\hline & Total & 12 & 100.0 & 12 & 100.0 \\
\hline \multirow{5}{*}{$\begin{array}{l}\text { Does the University respect the Muslim } \\
\text { students' way of life (e.g. social relations } \\
\text { between men and ladies, dress code, etc.)? }\end{array}$} & Disagree & 2 & 16.7 & 1 & 8.3 \\
\hline & Uncertain & 1 & 8.3 & - & - \\
\hline & Agree & 8 & 66.7 & 11 & 91.7 \\
\hline & Missing & 1 & 8.3 & - & - \\
\hline & Total & 12 & 100.0 & 12 & 100.0 \\
\hline \multirow{3}{*}{$\begin{array}{l}\text { Do you think the University's administration } \\
\text { acts as a role-model in its principles to } \\
\text { influence Muslim students to Christianity? }\end{array}$} & Disagree & 10 & 83.3 & 1 & 8.3 \\
\hline & Uncertain & 1 & 8.3 & 5 & 41.7 \\
\hline & Total & 12 & 100.0 & 12 & 100. \\
\hline \multirow{5}{*}{$\begin{array}{l}\text { Do you think the Muslim students have viewed } \\
\text { Christianity positively since the time you joined } \\
\text { this institution with respect to Adventism? }\end{array}$} & Agree & 4 & 33.3 & 1 & 8.3 \\
\hline & Uncertain & 5 & 41.7 & - & - \\
\hline & Disagree & 2 & 16.7 & 11 & 91.7 \\
\hline & Missing & 1 & 8.3 & - & - \\
\hline & Total & 12 & 100 & 12 & 100 \\
\hline
\end{tabular}


the administrators $(66.7 \%)$ involved in the study were uncertain on this issue, three agreed that the office do take care of its students, and one (8.3\%) administrator disagreed on this point.

From Table 3 it is also clear that the majority $(66.7 \%)$ of the student respondents disagreed that during worship time the service does take care of them as part of the congregation with a different spiritual background, two (16.7\%) agreed with this opinion, while the remaining number $(16.7 \%)$ were uncertain. Seven (58.3) of the administrators agreed that the worship time during services does take care of the Muslim students as part of its congregation, four (33.3\%) disagreed on this principle, while one $(8.3 \%)$ was uncertain about the matter.

According to Table 4 above, the majority of Muslim students $(83.3 \%)$ disagreed with the opinion that the way the Adventists handle their activities does influence someone to change their faith from Islam to Christianity, and only two $(16.7 \%)$ were uncertain about this issue. Most of the administrators $(66.7 \%)$ agreed with this opinion, two disagreed, while the remaining two $(16.7 \%)$ were uncertain about this issue. The difference in the two respondents' perception was emphasised by one administrator during an interview. He mentioned that the UEAB does not need to treat any group of students in any special way, hence the administrator's personal belief that the programmes offered are the best, even though it does not take care of this marginal group within the institution.

The findings in Table 4 also show that half $(50.0 \%)$ of the students disagreed that the Adventist's way of life does provide a clear picture of what God really expects in his children. Four $(33.3 \%)$ of the participants were uncertain, while only two (16.7\%) agreed with this statement.

The majority of the administrators (75.0\%) indicated that the Adventist way of life can lead people to conversion into Adventism, two of them (16.7\%) disagreed and only one (8.3\%) was uncertain. This concept was challenged by two administrators during an interview. They mentioned that the Adventist way of life implied that the majority of its adherents were caught up in acts of hypocrisy, which demonstrated that they regarded themselves as more righteous than others (Wuthnow 1994:367-368).

Regarding the issue of relationships, Table 4 also indicates that half of the Muslim students (50\%) agreed that Adventist students and administrators actually do view Muslim students as brothers and sisters. Even differences in religion did not challenge this opinion, because they indicated their belief that both Muslims and Christians were descendant of Abraham (Takim 2011:139). The other half (50\%) of Muslim respondents disagreed on this matter citing the superiority of the Holy Qur'an and the prophet Muhammad.

Most of the administrators (58.3\%) agreed that the Adventist students and administrators do actually view Muslim students as descendants of Abraham. Therefore, they are regarded as brothers and sisters in Christ despite their different religious affiliation. Three of the administrators $(25.0 \%)$ disagreed, and two $(16.7 \%)$ were uncertain on this issue. The difference in how the Muslim students perceive the way Christians appraise them is supported by the results of some of the interviews. A number of interviewees revealed that some Muslims have been led to prejudice by fellow Muslims students to such an extent that they are distrustful of any approach from the Christian community.

On the involvement of the Muslim students in the institution's spiritual activities, half of the students (50.0\%) responded negatively about being involved, four (33.3\%) agreed that they are involved, one $(8.3 \%)$ was uncertain, while one student $(8.3 \%)$ did not respond to this question. From the administrators' perspective, four (33.3\%) disagreed that Muslim students are involved, the same percentage were uncertain, three agreed that the Muslim students are normally involved in the institution's spiritual programmes, while one did not attempt to answer this question.

Table 4 also shows that the majority of the Muslim students (83.3\%) disagreed that the UEAB's recognition of special occasions (e.g. The Holy Month of Ramadhan, Worship time, Zalat, Sawm) allows them time to take part, while only two $(16.7 \%)$ agreed with this statement. Five of the administrators $(41.7 \%)$ agreed that the institution do take part in these occasions, the same percentage disagreed and two (16.7\%) were uncertain about this issue. One administrator commented during an interview that they do make food available for the Muslim students at the cafeteria during the Holy Month of Ramadan although he also hinted that the meal was nothing special but the ordinary food that every student received for supper.

Table 4 further indicates that the majority (66.7\%) of the students agreed that the UEAB do respect the Muslim students' way of life (e.g. social relations between men and women, dress code, etc.), two of the students (16.7\%) disagreed, one $(8.3 \%)$ was uncertain and one of the students did not respond to the question. Almost all of the administrators (91.7\%) involved in the study agreed that the University respects the Muslim students' way of life, while only one $(8.3 \%)$ disagreed on this aspect.

Findings from Table 4 further indicate that most Muslim students disagreed that the University's administration does act as a role-model according to its principles to influence Muslim students toward Christianity (Chow 2013). One student $(8.3 \%)$ was uncertain and one $(8.3 \%)$ did not respond to this question. On the other hand, half of the administrators $(50 \%)$ had a positive opinion on this issue, five of them were uncertain, while one (8.3\%) disagreed.

Finally, the Table 4 shows that four of the Muslim students (41.7\%) were uncertain whether they had viewed Christianity positively since the time they joined the Adventist institution 
as a Christian based institution. On this matter four (41.7\%) were uncertain, two (16.3\%) agreed that they had viewed Christianity positively and one (8.3\%) did not respond to the question. The majority of the administrators (91.7\%) indicated that Muslim students had viewed Christianity positively, while only one (8.3\%) agreed that Muslim students had a positive appraisal for Christianity and praised their way of life as a response to the Christian teachings available on campus (Comiskey 1998:17).

\section{Responses to open-ended questions}

The open-ended questions accessed how a Muslims' life style can influence a Christian's relationship with God and vice versa:

- The teaching of the Old Testament by the Adventist Church is a peculiar aspect that helps Muslims to improve their spiritual union with God.

- The Muslim students' devotion to prayer time has influenced the Adventist Christians' way of life and relationship with God.

- The honesty and obedience of Muslim students to their Islamic teaching and culture impacted positively on the UEAB as a whole.

- The zeal and total submission of the Muslims to the Prophet and Allah still poses a major challenge to the Christian community.

- The Muslim integration of religion and their daily lives according to their culture was their key to persevering with their faith in Islam.

\section{Summary of the findings}

The findings can be summarised as follows:

- The research exposed the discrepancy that exists at two levels: firstly, the administration has lost its vision in its policy making, because it does not adhere to the mission statement. Secondly, the implementation of the policy does not relate to the mission statement, because it lacks in context and approach. Whereas this mission statement was formulated with good intentions, its implementation requires an act critical contextualisation.

- I, as the researcher, perceive a relationship between the possible findings and those leading from my study that has already revealed a negative and apathetic attitude towards people of other faiths and particularly Muslims in this case.

- The findings only touched on relationship issues between Muslim and Christian students and the staff in general. A thorough study is required involving students from other faiths such as Hindus, Buddhists and animists.

- The findings highlighted the interaction between the Muslim students and the UEAB programmes at a general level. A probe into each individual programme would provide better results.

- Over the first few years of the UEAB's academic and religious calendar, the minimum baptisms seems to take place from students of other faiths and Muslims in particular, if any, and entry into the University church.
- Enrolled Muslim students seem detached from the UEAB's culture that displays a strong Western Adventism. The paradox is that the Muslim students continue enrolling into this seemingly 'hostile environment'. There is an apparent cultural clash and imminent potential conflict between the West and the Oriental East, viz. between Christianity and Islam at the UEAB. There also seems to be apparent compromises between the institution with its enthusiasm for mission, and the Muslim students with their zealous adherence to Puritanism.

\section{Conclusion}

The aim of the UEAB's mission statement was witnessing to and impacting on students of other faiths - Muslims included. This aim is not realised in the implementation and practice of the mission statement. There is a need to examine the spiritual programmes according to which many of the UEAB's students get baptised at the end of each quarter. Of importance is the lack of converts from students among other faiths Muslims in particular. To succeed, the UEAB needs to consider the following recommendations, among others:

- The UEAB, such as any other Christian institution, ought to examine its mission statement thoroughly to apply it effectively to students of other faiths and, in this case, the Muslim students.

- There is a need to revisit the Christian mandate and Great Commission as provided in Matthew 28:18-20 with regard to the understanding of spiritual programmes. This is because the power to reach out to students of other faiths is found within the promise that Christ will empower all those who would go with his mighty power that rules both the earth and heavens, and hence, by implication, rules the hearts of men and women to not only proclaim his goodness, but also to accept his ways.

- There is a need for practical implementation to address the issues of administration, serving students of other faiths contextually and adhering to the mission statement.

- A comparative system that deals with mission statements, for example that of chaplaincy departments within other institutions, can serve as model for church institutions such as the UEAB.

- There is a need to improve the training of personnel on issues such as handling students of other faiths - Muslims included. There is a need to introduce cultural anthropological topics where people are sensitised on issues regarding cultural forms in cross-cultural contacts.

- Financial resources should be allocated to operate programmes that target the students of other faiths, for example, by providing literature that address their challenges and help bridge the gap between Muslim and Christian students or other individuals within the institutions.

- The institution should allow Muslim students time to attend prayers (Khamsa sala) as a way to afford them freedom of worship, and hence winning them through friendship evangelism. Refusing them permission to worship on Fridays and allowing them to observe their month of Ramadhan is applying double standards. 
- The UEAB, as an institution, should use relevant mission approaches to introduce the Muslim students to Christ through evangelism. These include: (a) incorporating them into the Christian worshipping activities and orienting them in the Christian faith; (b) giving them the opportunity to meet their fellow Muslims in whatever religious activities they choose, as long as they don't interfere with normal worship and religious activities organised by the University's church, (c) enrolling them in the Adventist Christian-Muslim relations programmes organised by the church and (d) inviting and allowing them to participate in the dialogues between Adventists and Muslims that are normally organised by the Adventist-Muslim Relations department of the church. Such a gesture would challenge them to be obedient and embrace the Gospel.

- There is need to establish a strong Adventist-Muslim Center within the institution where all the Muslim students can be led to understand the relationship between the Sabbath in the Qur'an and Jesus' stance on the same issue.

\section{Acknowledgements Competing interests}

The author declares that she has no financial or personal relationships which may have inappropriately influenced her in writing this article.

\section{References}

Aden, L. \& Benner, D.G. (eds.), 1989, Counselling and the human predicament: A study of sin, guilt, and forgiveness, Baker, Grand Rapids, MI.

Aleaz, K.P., 2010, 'Theology of religions and the mission of the church', Asia Journal of Theology 24(2), 197-203.

Aleaz, K.P., 2011, 'Witnessing Christ in the company of Hindus', Asia Journal of Theology 25(1), 103-112.

Augsburger, D.W., 1986, Pastoral counselling across cultures, Westminster Philadelphia, PA.

Barger, R.C., 1966, Tomorrow in your hands: A guide for the Christian leaders and teachers of early teens and youths, Review \& Herald, Washington, DC.

Barna, G., 1998, The Second coming of the church, Word, Nashville, TA.

Bradfield, G., 2014, 'Growing Disciples Inventory (GDI) for self-assessment of Christian spiritual development', Journal of Research on Christian Education, 23(2), 130-153, viewed 23 September 2016, from http://www.tandfonline.com/doi/pdf/10.1080/ 10656219.2014.899478? needAccess=true

Beach, B.B., 1998, 'The church structural organization and acculturation. Adventist Responses to cross-cultural mission, 1, 1998-2001', in B.L. Bauer (ed.), Faith development in context: Presenting Christ in creative ways, pp. 1-9, Department of World Mission, Andrews University, Berrien Springs, MI.

Berry, J.W., Poortinga, Y.H., Segall, M.H. \& Dasen, P.R., 2002, Cross-cultural psychology: Research and applications, 2nd ed., Cambridge University Press, New York.

Bowman, A.N. \& Small, L.J., 2010, 'Do College students who identify with a privileged religion experience greater spiritual development? Exploring individual and institutional dynamics', Journal on Research in Higher Education 51(7), 595-614, viewed 13 November 2104, from http://eds.b.ebscohost.com.nwulib.nwu.ac.za/ ehost/pdfviewer/pdfviewer?sid=201199d0-0cb5-4263-8444-ea7825db0392\%40 sessionmgr111\&vid=19\&hid $=113$

Brown, D., 1976, A new threshold: Guidelines for the churches in their relations with Muslim communities, British Council of Churches, London.

Brummet, B., 1990, The spirited campus: The chaplain and the College Community, Pilgrim's Press, New York.

Chow, C.C.S., 2013, 'Guanxi and gospel: Conversion to Seventh-day Adventism in contemporary China', Journal of Social Sciences and Missions 26, 168-198, viewed 13 November 2014, from http://eds.b.ebscohost.com.nwulib.nwu.ac.za/ehost/ pdfviewer/pdfviewer?vid=12\&sid=201199d0-0cb5-4263-8444ea $7825 \mathrm{db0392} \% 40$ sessionmgr 111 \&hid $=113$

Comiskey, J., 1998, Home cell group explosion, Touch, Houston, TX.

Dizon, P.A., 2012, 'Issues in Adventist Muslim ministry', Journal of Adventist Mission Studies - Muslim Ministries 8(2), 5-17.
Doughlas, C.R., 1994, 'Ongoing strategy debate in Muslim missions', Journal of International frontier missions 2, 69-73, viewed 21 June 2016, from http://ijfm. International frontier missions 2, 69-73, viewed
org/PDFs_JFM/11_2_PDFs/04_Douglas_R.pdf

Duanne, E., 1993, Cross-cultural conflict: Building a relationship for effective ministry, InterVarsity Press, Westmont, IL.

Eastman, D., 1997, Beyond imagination: Simple plan to save the world, Chosen, Ada, MI.

Ernst, W.C., 2011, 'Reconfiguring South Asian Islam: from the 18th to the 19th century',. Journal of Comparative Islamic Studies, 5(2), 247-272, viewed 18 November 2104, from http://eds.a.ebscohost.com.nwulib.nwu.ac.za/ehost/ pdfviewer/pdfviewer?sid=727625bd-0c91-4f89-a2f3-c545dd9fedea\%40session mgr4005\&vid=11\&hid=4203

Fee, D.G., 1994, God's empowering presence: The Holy Spirit in the Letters of Paul, Hendrickson, Peabody, MA.

Francis, L. \& Astley, J., 1995, Critical perspectives for Christian education, Morehouse, New York.

Gardener, G.T., 2010, 'Challenges to Seventh-day Adventist tertiary education in the Caribbean', Online Journal of Research on Christian Education, 19(2), 197-209, viewed 13 November 2104, from http://eds.b.ebscohost.com.nwulib.nwu.ac.za/ ehost/pdfviewer/pdfviewer?vid=24\&sid=201199d0-0cb5-4263-8444ea7825db0392\%40sessionmgr111\&hid=113

Gould, P., 2014, 'An essay on academic disciplines, faithfulness, and the Christian scholar', Christian Higher Education, 13(3), 167-182, viewed 12 November 2104 from http://www.tandfonline.com/doi/pdf/10.1080/15363759.2014.904652

Grajales, T.G., Leon, V.H. \& Ellas, G., 2010, 'Christian education in Chile: Is the Seventhday Adventist system at risk?' Online Journal of Research on Christian Education 19(3), 224-239, viewed 13 November 2104, from http://eds.b.ebscohost.com nwulib.nwu.ac.za/ehost/pdfviewer/pdfviewer?sid=201199d0-0cb5-4263-8444-
ea7825db0392\%40sessionmgr111\&vid=23\&hid=113

Greenleaf, F., 2005, In passion for the Word: A history of Seventh-day Adventist education, Pacific Press, Toronto, Canada.

Grunland, S.A. \& Mayers, K.M., 1979, Cultural anthropology: A Christian perspective, Zondervan, Grand Rapids, MI.

Haviland, A., 1989, Anthropology, Holt Rinehart \& Winston, New York.

Hesselgrave, J.D., 2000, Planting churches cross-culturally: North America and beyond, 2nd edn., Baker Academic, Grand Rapids, MI.

Hewitt, R.R., 2014, 'Evangelism as discipleship: Implications for theological education and leadership formation', International Review of Mission 103(2), 200-214.

Hiebert, P.G., 2002, 'Cultural differences and the communication of the Gospel', in R.D. Winter \& S.C. Hawthorne (eds.), Perspectives on the World Christian Movement: A Reader, 3rd edn., pp. 373-383, William Carey Library, Pasadena, CA.

Ivermee, R., 2014, "Kipling, the "backward" Muslim, and the ends of colonial pedagogy: Nineteenth-century contexts', An Interdisciplinary Online Journal, 36(3), 251-268, viewed 18 November 2104, from http://eds.a.ebscohost.com. nwulib.nwu.ac.za/ehost/command/detail?sid=727625bd-0c91-4f89-a2f3-c545dd 9fedea $\% 40$ sessionmgr4005\&vid=7\&hid $=4203$

Kraft, C.H., 1996, Anthropology for Christian witness, Orbis, Maryknoll, NY.

Kraft, C.H., 2002, 'Culture, worldview and contextualization', in R.D. Winter \& S.C. Hawthorne (eds.), Perspectives on the World Christian Movement: A Reader, 3rd edn., pp. 384-391, William Carey Library, Pasadena, CA.

Laing, C., 2013, 'A provocation to mission: Constance Padwick's study of Muslim devotion', Islam and Christian-Muslim Relations, 24(1), 27-42, viewed 18 November 2104, from http://eds.b.ebscohost.com.nwulib.nwu.ac.za/ehost/ command/detail?sid=666bcf80-7d72-474a-8b45-e1fb94246b0f\%40sessionmgr1 $10 \&$ vid $=4$ \&hid $=119$

Makondo, L. \& Makondo, O., 2011, 'Funeral songs and the Seventh-day Adventist Church', Journal of Music Research in Africa 8(1), 70-81, viewed 13 Novembe 2104, from http://eds.b.ebscohost.com.nwulib.nwu.ac.za/ehost/command/ detail? sid=201199d0-0cb5-4263-8444-ea7825db0392\%40sessionmgr111\&vid=1 $5 \&$ hid $=113$

McVay, J., 2005, 'Response to Peter Roennfeldt's paper: Faith development in context - an overview', in B.L. Bauer (ed.), Faith development in context: Presenting Christ in creative ways, pp. 49-55, Department of World Mission, Andrews University, Berrien Springs, MI.

Mugambi, J.N.K., 2013, 'Missionary presence in interreligious encounters and relationships', Studies in World Christianity 19(2), 162-186, viewed 11 November 2104, from http://eds.a.ebscohost.com.nwulib.nwu.ac.za/ehost/pdfviewer/ pdfviewer?vid $=25 \&$ sid $=d 3$ addfbc -5 f $85-474 c-9 d 1$ e- 5 f364d070e 5 e $\% 40$ sessionmgr4004\&hid=4110

Osindo, O., 2005, 'Relating to Muhammad and the mosque', in B.L. Bauer (ed.), Faith development in context: Presenting Christ in creative ways, pp. 49-55, Department development in context: Presenting Christ in creative ways,
of World Mission, Andrews University, Berrien Springs, MI.

Parshall, P., 2002, 'Going too far?', in R.D. Winter \& S.C. Hawthorne (eds.), Perspectives on the World Christian Movement: A reader, 3rd edn., pp. 655-663, William Carey Library, Pasadena, CA.

Patrick, A., 2010,'Contextualizing recent tensions in Seventh-day Adventism: A constant struggle of struggle and rebirth?', Theology Papers and Journal Articles, $15,1-15$.

Pratt, D., 2005, The Challenge of Islam: Encounters in interfaith dialogue, Ashgate, Burlington, $\mathrm{VT}$.

Ramirez, O., Ashley, G. \& Cort, M., 2014, 'What does it mean to be a Christian? Exploring the religious identity of intrinsically and extrinsically religious Black Exploring the religious identity of intrinsically and extrinsically religious Black
Seventh-day Adventist university students', Journal of Research on Christian Seventh-day Adventist university students', Journal of Research on Christian
Education, 23(1), 56-69, viewed 13 November 2104, from http://eds.b.ebscohost. Education, 23(1), 56-69, viewed 13 November 2104, from http://eds.b.ebscohost. com.nwulib.nwu.ac.za/ehost/command/detail?sid $=2$
ea7825db0392\%40sessionmgr111\&vid=10\&hid $=113$ 
Sauer, C., 2013, "'To flee or not to flee": Responses to persecution and the issue of relocation' Missionalia 41(1), 53-65, viewed 4 July 2105, from http://www.scielo. org.za/pdf/mission/v41n1/05.pdf

Sayyid, H.A. \& Majtaba, M.L., 1997, Ethics and spiritual growth, Foundation of Islamic Cultural Propagation in the World, Qum.

Schielke, S., 2007, 'Hegemonic encounters: Criticism of Saints-Day Festivals and the formation of modern Islam in late 19th and early 20th-century Egypt', Journal of Welt des Islams 47(3\&4), 319-355, viewed 18 November 2104, from http:// eds.a.ebscohost.com.nwulib.nwu.ac.za/ehost/pdfviewer/pdfviewer?sid= 727625 bd-0c91-4f89-a2f3-c545dd9fedea\%40sessionmgr4005\&vid $=19 \& \mathrm{~h}$ id $=4203$

Scott C.E. \& Randallb, E.V., 2014, 'Living in two worlds: The development and transition of Mormon education in American society', Journal of the History of Education, 43(1), 3-30, viewed 11 November 2104 , from http://dx. doi.org/10.1 080/0046760X.2013.844276http://dx.doi.org/10.1080/0046760X.2013.844276

Shaw, H.W.P., 2014, “"New treasures with the old": Addressing culture and gender imperialism in higher level theological education', Evangelical Review of Theology $38(3), 265-279$.

Shibley, D., 1997, A force in the earth: The Holy Spirit and world evangelization, Creation House, Lake Mary, FL.

Siddiqui, A., 2010, 'Inter-faith relations in Britain since 1970 - an assessment', Exchange 39(3), 236-250.

Siemens, R.E., 1997, 'The vital role of tent making in Paul's mission strategy', International Journal of frontier missions 14(3), 121-129, viewed 21 June 2016, from http://ijfm.org/PDFs_IJFM/14_3_PDFs/06_Siemens.pdf

Smith, I.J., 1998, 'Christian missionary views of Islam in the nineteenth and twentieth centuries', Islam and Christian-Muslim Relations 9(3), 357, October viewed 12 May 2014 from http://www.informaworld.com/smpp/content content $=\mathrm{a} 777417010 \sim \mathrm{db}=\mathrm{all}$

Sophie, R.G., 2000, Religion in higher education: The politics of the multi-faith campus, Ashgate, Farnham.
Taizé, B.J., 2014, 'Transmitting the message of the Gospel to youth', International Review of Mission, 103(2), 227-239.

Takim, L., 2011, 'Peace and war in the Qur'an and Juridical literature: A comparative perspective', Journal of Sociology \& Social Welfare 38(2), 137-157.

Taylor, V.J., 1972, The go-between God: The Holy Spirit and Christian mission, SCM, Bristol.

UEAB see University of Eastern Africa Baraton.

University of Eastern Africa Baraton, 2008, UEAB Mission and Statement, viewed 28 January 2014, from www.ueab.ac.ke/mission, objective.http

Volz, S., 2014, 'The rise and fall of the Moffat Institution: Mission education in a colonial borderland', South African Historical Journal 66(3), 470-485, viewed 12 November 2104, from http://dx.doi.org/10.1080/02582473.2014.881910

White, D.E., 2011, 'Idolatry, Evangelicalism, and the intense objectivism of Robert Southey', Romanticism in Edinburgh University Press 17(1), 39-51, viewed 18 November 2104, from http://eds.a.ebscohost.com.nwulib.nwu.ac.za/ehost/ pdfviewer/pdfviewer?vid=12\&sid=727625bd-0c91-4f89-a2f3-c545dd9fedea $\% 40$ sessionmgr4005\&hid $=4203 y$

Whitehouse, J., 1998, 'Developing new church structures for more effective mission, nurture, and growth of new believers', in B.L. Bauer (ed.), Adventist responses to cross-cultural mission: Global mission issues committee papers, 1998-2001, vol. 1, pp. 35-52, Department of World Mission, Berrien Springs, MI.

Wiklander, B., 1998, 'The boundaries of contextualization in mission: How flexible and absolute are they? What principles should guide the church?', in B.L. Bauer, (ed.), Adventist responses to cross-cultural mission: Global mission issues committee papers, 1998-2001, vol. 1, pp. 91-129, Department of World Mission, Berrien Springs, MI.

Wiklander, B., 2002, 'The fundamental beliefs and globalization', in B.L. Bauer (ed.), Adventist responses to cross-cultural mission, 2002-2005, vol. 2, pp. 1-9, Department of World Mission, Andrews University, Berrien Springs, MI.

Wuthnow, R. (ed.), 1994, 'I come away stronger': How small groups are shaping American religion, Eerdmans, Grand Rapids, MI. 